DOI https://doi.org/10.30525/978-9934-26-114-5-5

\title{
ФОРМУВАННЯ ПРИЙНЯТТЯ МАТЕРИНСЬКОЇ РОЛІ У ПРЕНАТАЛЬНОМУ ПЕРІОДІ
}

\author{
Лсеняк А. 0. \\ аспірант факультету психології \\ Національний педагогічний університет імені М. П. Драгоманова \\ м. Київ, Україна
}

Особливість періоду вагітності стосується як матері, так і дитини. Ці стосунки мають особливий характер, оскільки формуються ще до народження дитини. Дитина живе в матері з перших днів ії існування, i вони є фізичною та емоційною єдністю, взаємодіючи між собою.

Залежно від виникнення та сили певних факторів, перший період після зачаття - це час надзвичайно сильних і напружених переживань для жінки. У деяких 3 них переважають почуття гордості та сили, жвавість, активність, радість та піднесення, ентузіазм та життєвий тонус.

Для інших - це руйнування життєвих планів і прагнень, серед яких не було планування та готовності до дитини. У батьківському досвіді $\epsilon$ потенціал для унікальних переживань, але іноді він залишається непоміченим, оскільки основна увага приділяється переживанню хронічної печалі за втраченою свободою.

$\mathcal{E}$ три етапи розвитку материнського ставлення: 1 . період з раннього дитинства до настання вагітності жінки, 2. період вагітності та пологів, 3. період від народження дитини до віку 3-4 місяців.

Протягом цього часу, більш-менш усвідомленим, жінка дізнається обсяг обов'язків матері, найчастіше виходячи зі схем, що спостерігаються в сімейних цінностей під час зростання, а потім (в результаті їх затвердження як тих, які вона хотіла б дублювати або ставити під сумнів та відхиляти їх), вона формує власну ідею та спосіб їх реалізації. Дослідження, показують, що жінки частіше копіюють поведінку з родини, ніж свідомо створюють своє власне бачення. Саме тому, так важливо, щоб уявлення про материнство та подальша поведінка, які відклалися з дитинства, були правильною моделлю, що гарантуватиме гармонійне втілення у подальшому житті.

Перший етап вагітності, що відрізняється від звичного стану, включає нові для жінки самовідчуття, які є сигналами процесів, що відбуваються в її організмі (наприклад, збільшення грудей, зміна смаку та підвищена відраза до певної їжі або підвищений апетит 
до них, нудота, печія, зміни зовнішнього вигляду, підвищена сонливість, втома).

Друга група змін відноситься вже до психічної сфери і в основному пов'язана 3 підвищеною чутливістю та емоційною лабільністю, дратівливістю, порушеннями уваги та пам'яті. Це називається нормальний аутичний період, що характеризується самоконтролем жінки та неможливістю перейти від мислення «я» до мислення ми.

Саме другий етап і відрізняється тим, що протягом своєї тривалості увага поступово переходить до дитини, що розвивається. Відчуття рухів плоду допомагає розпізнати його індивідуальність і реально уявити це. Від партнера / батька дитини жінка очікує більшої підтримки, пов'язаної з повсякденною діяльністю, підготовкою до народження дитини та емоційною підтримкою.

Найважливішим завданням третього етапу є підготовка до пологів. Це часто асоціюється із збільшенням невизначеності, тривоги, страхів щодо цієї події (iї перебігу, болю, ускладнень та наслідків цих ускладнень).

Як видно з вищевикладеного, ці три стадії йдуть послідовно, показуючи, що дозрівання до ролі матері - це процес.

Вагітність можна розглядати - в крайніх формах - 3 точки зору ваги (фізичної, фінансової, рухової, розумової; вага кожного відрізняється) та благодатного стану - як два кінці одного виміру (хоча між ними природно багато проміжних станів ). Багато жінок відчувають помірну депресію, особливо протягом перших 8-10 тижнів, а стосунки матері та дитини в цей період характеризуються суперечливими думками та почуттями - від повного прийняття до неприйняття, припускаючи часто різні значення і відтінки амбівалентності щодо зачатої дитини. Важливо усвідомити, що материнство включає процес, який набувається тільки з часом. Стати і бути матір'ю, прийняття цієї нової ролі матері може бути довготривалим процесом, коли вона (іноді дуже повільно) виростає до материнства під впливом поєднання індивідуальних та соціальних факторів. У процесі цього поступового дозрівання зміст та інтенсивність материнського досвіду, навичок та обов'язків постійно змінюються та збагачуються.

Найважливіші завдання в період вагітності для жінки це: забезпечення безпеки себе та дитини під час вагітності та пологів, прийняття дитини важливою особою в сім'ї, встановлення зв'язку 3 дитиною, народження та адаптуватися до нових завдань материнства. Ïх ефективне виконання $\epsilon$ однією $з$ умов плавного вступу в саму материнську роль після пологів.

Однак народження материнської любові не обов'язково відбувається одночасно із зачаттям дитини. Це прийняття хоч і $€$ очевидним, 
але не підтверджує пробудження «материнського інстинкту», а лише $\epsilon$ реакцією на сильний тиск соціальних очікувань у культурі, де материнство вважається головною особливістю нормальної дорослої жінки (мається на увазі, що жінки, які бажають бути нормальними, підпадають під «обов'язок бути матір'ю) і в якому «успішне материнство» є суттю жіночої ідентичності. Ми досі маємо справу саме 3 таким соціальним примусом, заснованим на переконанні, що материнство $є$ обов'язковою жіночою соціальною роллю.

Кожна вагітність змінює сенс і мету життя, провокуючи потребу жінки в адаптації до нової ситуації. Немовлята - це ніби матеріал, 3 якого буде створено власне Я. Кожен з них має певний генотип та унікальний спектр можливостей. Їх організм запрограмований на певний розвиток, але це, звичайно, не $є$ автоматичною програмою. Цей процес зумовлений ранніми переживаннями, що становлять невидиму історію життя, сформовану особою матері, започаткованою в період внутрішньоутробного життя. Розвиток дитини до народження - це процес змін, які запрограмовані генетично, але які також залежать від внутрішнього та зовнішнього впливу. Чим раніше стадія розвитку, тим інтенсивніші темпи змін і більша чутливість до факторів, які можуть змінити те, що було спадковим. Таким чином, вплив матері починає спрацьовувати ще до народження дитини, і це, як кажуть деякі, також через її ставлення до нього. Тут важливим є зріла любов обох батьків, що означає готовність прийняти та виховувати дитину.

Вагітність розуміється як час екзистенційно значущих подій у житті людини та протистояння з батьківською роллю, яке стає реальним у конкретних поєднаннях життєвих ситуацій або на яку людина повинна відповісти та зробити вибір бо вони і є результатом загальних, якісних змін у розвитку психофізичного характеру та соціокультурних факторів.

Материнство в його пренатальній фазі слід розглядати як особливий та важливий елемент, оскільки якість материнства, яке переживає дитина $з$ перших днів іiї життя і до дорослості, багато в чому визначає, якою людиною вона стане. Саме турбота про жінок, які чекають дитину, є інвестицією у розвиток суспільства. Оскільки вагітність започатковує батьківські ролі і $€$ носієм значень, пов'язаних 3 материнством, дородовий догляд та освіта повинні здійснюватися до періоду зачаття, і не обмежуватися сферою здоров'я та використання накопичених знань лише в галузі медицини та акушерства. Їх слід поширювати на психолого-педагогічні науки.

Цей фон розвитку культури, який відіграє основні функції у формуванні ставлення материнства, включає тривалий процес вивчення значень систем цінностей. Особливу роль відіграє внутрішня сімейна 
соціалізація, завдяки якій дитина та майбутні батьки реконструюють образ навколишньої дійсності та вибудовують систему коннотаційних значень, також пов'язаних із вагітністю та потенційним чи справжнім материнством та батьківством. Прийняття материнської ролі повинно відбуватися на декількох рівнях одночасно: свідомому та несвідомому, соціальному, інтелектуальному, фізичному та емоційному. Саме таке поєднання дає позитивну перспективу благополучного перебігу вагітності, народженню та виховання здорової особистості.

\title{
Література:
}

1. Гроф С. За пределами мозга: Рождение, смерть и трансценденция в психотерапии. - 3-е изд. - М.: Ин-т Трансперсональной Психологии, Изд-во Ин-та Психотерапии, 2000

2. Даниленко Н.В. Методи дослідження готовності до материнства. Н.В.Даниленко // Вi- сник ХНПУ ім. Г.С.Сковороди. Психологія. Харків, 2005. - Вип. 15

3. Филиппова Г.Г. Материнство и основные аспекты его исследования в психологии / Г.Г Филиппова // Вопросы психологии. С. 4.

4. Яремчук Н.В. Психологічні особливості готовності молодої жінки до майбутнього материнства / Н.В.Яремчук // Вісник піс-лядипломної освіти: зб. наук. пр. / [редкол. В.В.Олійник (голов. ред.) та ін.]. - К., 2008. -Вип. 7.

DOI https://doi.org/10.30525/978-9934-26-114-5-6

\section{PROFESSIONAL RESPONSIBILITY OF THE FUTURE TEACHERS: THE ESSENCE AND PROBLEM OF FORMATION}

\author{
Meshko H. M. \\ Dr. of Pedagogy, Professor,
} Head of the Department of Pedagogy and Education Management Ternopil Volodymyr Hnatyuk National Pedagogical University

Meshko O. I.

Ph.D. of Psychology, Associate Professor, Associate Professor of the Department of Psychology Ternopil Volodymyr Hnatyuk National Pedagogical University

Ternopil, Ukraine

Today the school needs a new generation teacher with a formed professional and pedagogical position, competent, reliable, and responsible. 